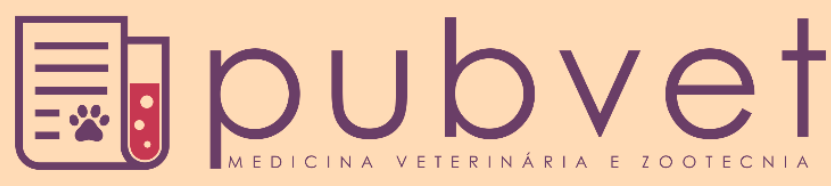

https://doi.org/10.31533/pubvet.v15n07a866.1-9

\title{
Evolução da peritonite infecciosa felina da forma úmida para seca: Relato de caso
}

\author{
Renara Lima Benicio da Cunha ${ }^{1^{*} \bullet}$, Edilene Pereira de Sousa ${ }^{2+}{ }^{\bullet}$, Ana Rafaella Vieira Guedes ${ }^{2}$, \\ Shayanne Sayonara da Costa Silva ${ }^{10}$, Lílian Ribeiro Barreto ${ }^{1 \bullet}$, Berlamino Eugênio Lopes \\ Neto $^{3}$, Daniel Amed de Oliveira ${ }^{2}{ }^{\circ}$, Jayana Martins Barbosa ${ }^{2} \odot$ \\ ${ }^{1}$ Médica Veterinária, Universidade Estadual do Ceará, Faculdade de Veterinária, Ceará, Brasil. \\ ${ }^{2}$ Graduando(a) em Medicina Veterinária, Universidade Estadual do Ceará, Faculdade de Veterinária, Ceará, Brasil. \\ ${ }^{3}$ Docente da Faculdade de Medicina Veterinária da Universidade Estadual do Ceará-UECE. \\ †In Memoriam \\ *Autor para correspondência, E-mail: renaralima54.2@gmail.com
}

Resumo. A peritonite infecciosa felina (PIF) é uma doença imunomediada fatal, desencadeada por formas mutadas do coronavírus felino. Apresenta duas formas: PIF efusiva ou úmida caracterizada pelo acúmulo de fluidos cavitários e PIF não efusiva ou seca que leva ao desenvolvimento de lesões granulomatosas a piogranulomatosaso. $\mathrm{O}$ diagnóstico presuntivo da doença pode ser realizado através da avaliação do histórico do animal, achados clínicos e resultados laboratoriais, já o definitivo se dá por meio do histopatológico e imuno-histoquímica. O tratamento é de suporte e pouco efetivo, havendo indícios sobre a possível eficácia de antivirais e imunomoduladores. O objetivo do trabalho é relatar um caso de peritonite infecciosa felina em um felino sem raça definida, fêmea com idade aproximada de um ano, destacando os aspectos clínicos, laboratoriais e patológicos da enfermidade. No exame físico notou-se presença de líquido no abdômen e dispneia leve, foi solicitado a princípio ultrassom abdominal, observou-se alterações em diversos órgãos, como rins e alças intestinais. Alterações também foram encontradas em outros exames como hemograma (anemia, leucocitose e trombocitopenia), bioquímico (aumentado de creatinina, ureia, AST, ALT), analise do líquido (relação albumina/globulina baixa e positivo no teste de Rivalta), PCR (positivo para coronavírus felino), raio-X (pneumonia) e na necrópsia notou-se alteração no baço, rins, fígado, intestino e pulmão. O diagnóstico foi realizado pela associação do histórico do animal, exame físico e de todos os exames realizados para chegar à conclusão de PIF. O tratamento não parou a progressão da doença, o felino começou a apresentar sinais neuro- lógicos característicos da PIF seca e veio a óbito dias depois. Tendo sobrevivido mais de 30 dias desde o início dos sintomas.

Palavras chave: Diagnóstico, felino, peritonite infecciosa felina

\section{Evolution of feline infectious peritonitis from wet to dry: Case report}

\begin{abstract}
Feline infectious peritonitis (PIF) is a fatal immune-mediated disease, triggered by mutated forms of feline coronavirus. It presents two forms: effusive or wet FIP characterized by the accumulation of cavitary fluids and non-effusive or dry FIP that lead to the development of granulomatous to pyogranulomatous lesions, potentially in the parenchyma. of any organ. The presumptive diagnosis of the disease can be made through the evaluation of the animal's history, clinical findings and laboratory results, whereas the definitive one is made through histopathological and immunohistochemistry. The treatment is supportive and ineffective, with evidence on the possible effectiveness of antivirals and immunomodulators. The objective of the work is to report a case of feline infectious peritonitis in a mixed breed female, approximately one year old, highlighting the clinical,
\end{abstract}


laboratory and pathological aspects of the disease. On physical examination, the presence of fluid in the abdomen and mild dyspnea was noted, abdominal ultrasound was requested at first, and changes were observed in several organs, such as kidneys and intestinal loops. Changes were also found in other tests such as blood count (anemia, leukocytosis and thrombocytopenia), biochemical (increased creatinine, urea, AST, ALT), fluid analysis (low albumin / globulin ratio and positive in the Rivalt test), PCR (positive for feline coronavirus), X-ray (pneumonia) and at necropsy, changes in the spleen, kidneys, liver, intestine and lung were noted. The diagnosis was made by associating the animal's history, physical examination and all the examinations performed to reach the conclusion of PIF. The treatment did not stop the progression of the disease, the feline began to show neurological signs characteristic of dry PIF and died a few days later. Having survived more than 30 days since the onset of symptoms.

Keywords: Diagnosis, feline, feline infectious peritonitis

\section{Evolución de la peritonitis infecciosa felina de la forma húmeda para seca: Reporte de un caso}

Resumen. La peritonitis infecciosa felina (PIF) es una enfermedad inmunitaria mortal, desencadenada por formas mutadas de coronavirus felino. Tiene dos formas: FIP efusiva o húmeda caracterizada por la acumulación de fluidos de cavidad y FIP no efusiva o seca que conduce al desarrollo de lesiones granulomatosas a piogranulomatosas. El diagnóstico presuntivo de la enfermedad se puede realizar mediante la evaluación de la historia del animal, hallazgos clínicos y resultados de laboratorio, mientras que el definitivo se realiza mediante histopatología e inmunohistoquímica. El tratamiento es de apoyo e ineficaz, con indicios de la posible eficacia de los antivirales y los inmunomoduladores. El objetivo del trabajo es reportar un caso de peritonitis infecciosa felina en una hembra de raza mixta, de aproximadamente un año de edad, destacando los aspectos clínicos, de laboratorio y patológicos de la enfermedad. Al examen físico se constató la presencia de líquido en el abdomen y leve disnea, se solicitó en un primer momento una ecografía abdominal y se observaron alteraciones en varios órganos, como riñones y asas intestinales. También se encontraron cambios en otras pruebas como hemograma (anemia, leucocitosis y trombocitopenia), bioquímica (aumento de creatinina, urea, AST, ALT), análisis de fluidos (relación albúmina / globulina baja y positivo en la prueba de Rivalta), PCR (positivo para coronavirus felino), rayos X (neumonía) y en la necropsia, se observaron cambios en el bazo, riñones, hígado, intestino y pulmón. El diagnóstico se realizó asociando la historia del animal, el examen físico y todos los exámenes realizados para llegar a la conclusión de la PIF. El tratamiento no detuvo la progresión de la enfermedad, el gato comenzó a mostrar signos neurológicos característicos de FIP seco y falleció a los pocos días. Sobreviviendo más de 30 días desde el inicio de los síntomas.

Palabras clave: Diagnóstico, felino, peritonitis infecciosa felina

\section{Introdução}

A peritonite infecciosa felina (PIF), surgida nos primórdios da década de 1950, é uma doença imunomediada fatal, desencadeada por formas mutadas do coronavírus felino (FCoV), um RNA-vírus envelopado de fita simples, frequentemente encontrado nos felinos domésticos, mas também selvagens de vida livre (Jericó et al., 2015).

Os fatores predisponentes a doença são: faixa etária (animais de seis meses a dois anos de idade e gatos idosos), predisposição racial (Persa, Abssínio, Bengal, Birmanês e Himalaio), superpopulação em gatis e abrigos, desnutrição, doenças infecciosas crônicas e concomitantes como Leucemia Viral Felina (FeLV) e Imunossupressão Viral Felina (FIV) e uso de fármacos imunossupressores (Little, 2016). 
A imunidade do hospedeiro é importante no desenvolvimento da doença clínica. Os gatos que apresentarem forte resposta imunológica celular paralelamente à resposta humoral estarão protegidos contra a doença, em contraste, os animais que desenvolverem fraca resposta imunológica celular apresentarão a forma efusiva da PIF e, consequentemente, aqueles que desenvolverem resposta celular parcial apresentarão a forma não efusiva (Megid et al., 2016).

Os sinais clínicos variam, como anorexia, inapetência, letargia, perda de peso, febre, diarreia, icterícia, neurológicos, oftálmicos e envolvimento de trato respiratório superior. Apresenta duas formas: PIF efusiva ou úmida caracterizada pelo acúmulo de fluidos cavitários, principalmente peritoneal, com coloração amarelada, aspecto límpido a moderadamente turvo e consistência viscosa e PIF não efusiva ou seca que não leva ao desenvolvimento de efusões, mas de lesões granulomatosas a piogranulomatosas, potencialmente no parênquima de qualquer órgão (Megid et al., 2016).

O diagnóstico presuntivo da doença pode ser realizado através da avaliação do histórico do animal, achados clínicos e resultados laboratoriais. Exames de imagem, como radiografia e ultrassonografia são úteis para identificar efusões, em gatos com aumento abdominal ou dispneia. A reação da transcriptase reversa seguida de reação em cadeia da polimerase (RT-PCR) pode ser usada para detecção do vírus, os resultados devem ser interpretados em conjunto com outros achados clínicos e não pode ser usado como o único critério para o diagnóstico da PIF, visto que não é possível diferenciar quando a infecção é por coronavírus enterico felino (CVEF) ou VPIF (Sharif et al., 2010). Assim como testes sorológicos que já estão disponíveis. Histologicamente, a PIF consiste de uma inflamação predominantemente piogranulomatosa localizada ao redor de vasos, principalmente de vênulas, o diagnóstico definitivo se dá por meio do histopatológico e imunoistoquímica (Oliveira et al., 2003; Uliana et al., 2013).

O tratamento é de suporte e pouco efetivo, havendo indícios sobre a possível eficácia de antivirais e imunomoduladores, porém, com taxa de sobrevivência não ultrapassando 5\% em um período de um ano a partir do diagnóstico (Pedersen, 2014). Diante do exposto, o presente trabalho teve por objetivo relatar um caso de peritonite infecciosa felina, destacando os aspectos clínicos, laboratoriais e patológicos da enfermidade.

\section{Material e métodos}

Foi atendido em uma clínica veterinária localizada em Fortaleza, Ceará, no dia 17 de janeiro de 2020, um felino sem raça definida, fêmea com idade aproximada de um ano, castrada, pesando cerca de 2,8 $\mathrm{kg}$, com queixa principal de que a barriga do animal estava aumentando de volume. Na anamnese, a tutora relatou que o animal foi retirado das ruas no final de dezembro e passou por uma ovariosalpingohisterectomia há duas semanas, aproximadamente uns dois dias, notou que a barriga do animal está aumentando de tamanho, respiração estava alterada, febre intermitente e alimentando-se pouco. Relatou ainda que o animal apresentou um quadro de constipação há uma semana e que o mesmo foi tratado com lactulona, metoclopramida e ranitidina, tendo obtido melhora clínica com a terapêutica. No momento da consulta estava urinando e defecando normalmente. Não sabia informa se era vacinado, mas estava com a vermifugação em dias.

No exame clínico físico, notou-se evidente aumento de volume abdominal (Figura 1), com incomodo à palpação do abdome, sendo positiva para a prova de ondulação, leve dispneia, pelagem eriçada e estado nutricional um pouco abaixo do normal.

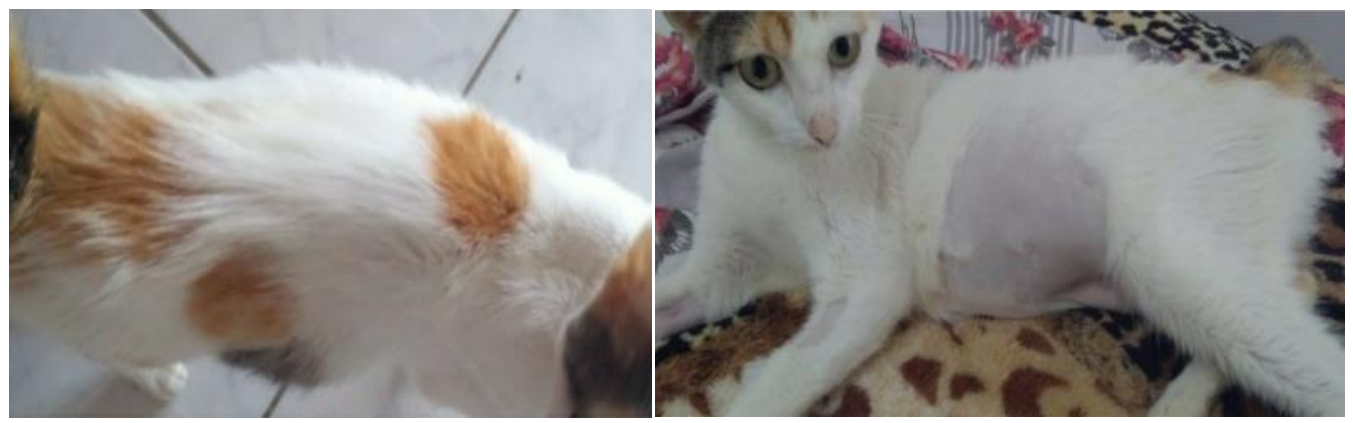

Figura 1. Fêmea felina com aumento de volume abdominal. 
$\mathrm{O}$ animal apresentava mucosas ocular e gengival normocoradas e temperatura retal normal, assim como os demais parâmetros. Foi requisitado a princípio ultrassom abdominal e do tórax (para confirma efusão) que foi realizada no mesmo dia. E posteriormente hemograma, perfil bioquímico (ureia, creatinina, proteínas totais, albumina, AST, ALT, fosfatase alcalina, globulina e razão albumina/globulina, análise do líquido cavitário abdominal e raio-X do tórax.

\section{Resultados}

No dia 17 Janeiro de 2020 foi realizado exame ultrassonográfico, notou-se rim com contorno aparentemente um pouco irregular e perda de definição corticomedular (Figura 2), fígado aumentado, estômago com espessamento da parede (gastrite) e dilatado com presente de conteúdo gasoso/mucoide e líquido, baço discretamente aumentado, alças intestinais levemente espessadas em duodeno (duodenite) e com peristaltismo evolutivo reduzido, bexiga revelou parede espessada e com celularidade (cistite), peritonite, linfonodos mesentéricos aumentados (principalmente o gastroduodenal) e com reação inflamatória, além de presença de líquido livre (LL) no abdômen e no tórax. Foi coletado 0,5 ml do líquido por abdominocentese, o qual se mostrava com aspecto translucido, em seguida realizou-se teste de Rivalta que deu negativo.

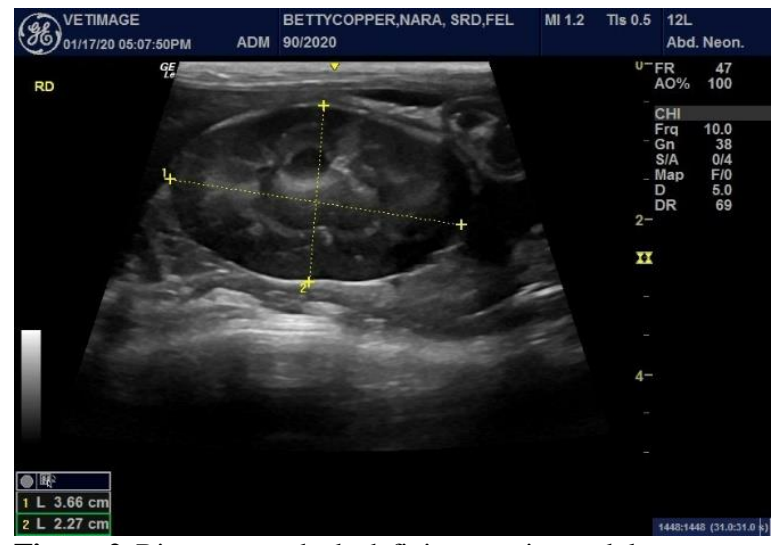

Figura 2. Rim com perda de definição corticomedular.

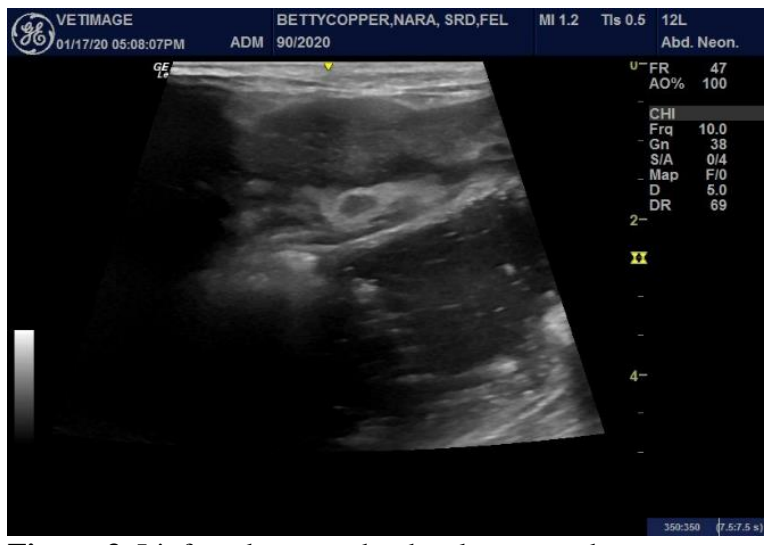

Figura 3. Linfonodo gastroduodenal aumentado.

Com base na anamnese, exame clínico e achados ultrassonográficos, suspeitou-se de peritonite infecciosa felina. A terapêutica foi iniciada com prednisolona $1 \mathrm{mg} / \mathrm{kg}$ SID e suplemento vitamínico (Glicopan) 1,5 ml SID, ambos por via oral, aplicação semanal de vitamina B12 na dose $100 \mathrm{mcg} /$ animal por via subcutânea até novas recomendações. Em casos de febre foi recomendado dipirona na dose de $25 \mathrm{mg} / \mathrm{kg}$ SID. No dia 29 de janeiro foram realizados os seguintes exames: hemograma, bioquímico, análise do líquido, raio x do tórax e outro USG no centro de diagnóstico veterinário (CDV).

No hemograma completo, foi evidenciado anemia, valores de hemácias, hemoglobina e hematócrito abaixo dos valores de referência, já no leucograma revelou leucocitose por neutrofilia e linfopenia, alteração no número de plaquetas, revelando trombocitopenia com discreta plaqueta gigante. $\mathrm{Na}$ análise bioquímica observou-se alteração nos valores de creatinina, ureia, albumina e relação alb/glob que estavam abaixo do valor de referência, além das proteínas totais, globulina e AST que estavam aumentados.

$\mathrm{Na}$ análise do líquido abdominal, que foi obtida por abdominocentese, no exame físico, o líquido apresentava coloração amarelo-palha, turvo, com densidade de 1048. No químico, realizado com tiras reagentes, foi observado presença de glicose, sangue, proteína $100 \mathrm{mg} / \mathrm{dL}, \mathrm{PH}: 8$. Apresentou-se positivo para o teste de Rivalta (Figura 4) e relação albumina/globulina com valor de 0,5.

$\mathrm{Na}$ citologia, foi evidenciado uma amostra com presença de células inflamatórias, apresentando predomínio de neutrófilos (93\%) seguido por linfócitos (7\%). Não foram observados microorganismos na amostra. Diante do exposto, o líquido foi caracterizado como exsudato inflamatório supurativo. Foi encaminhada amostra para realização do PCR, com resultados positivos confirmando a presença de Coronavírus felino (FcoV) no líquido ascítico. 
No ultrassom abdominal notou-se as mesmas alterações que foram descritas no primeiro exame ultrassonográfico com grande quantidade de líquido livre na cavidade abdominal (Figura 5), mas o rim já apresentava sinal de medular e observou- se líquido livre.

O raio-X foi realizado na posição laterolateral e ventrodorsal, evidenciou que o animal apresentava discreta efusão no tórax, notou-se alteração no pulmão sugerindo um padrão brônquio intersticial infiltrativo, caracterizando uma pneumonia.

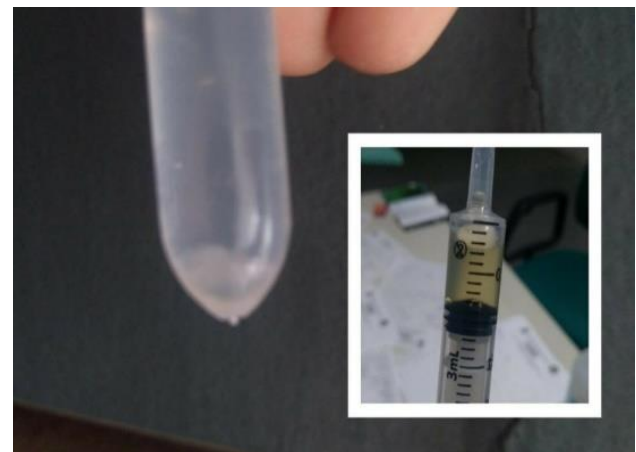

Figura 4. Teste de Rivalta positivo, gota formada se depositando no fundo.

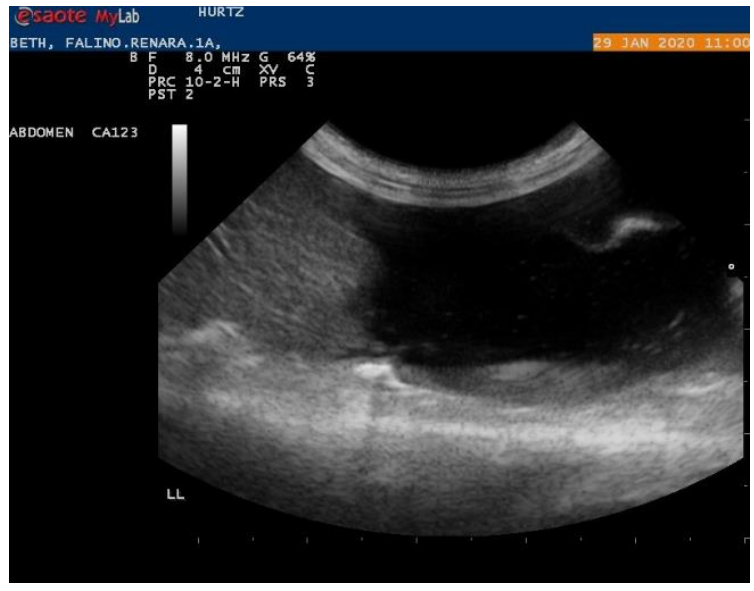

Figura 5. Líquido livre na cavidade abdominal.

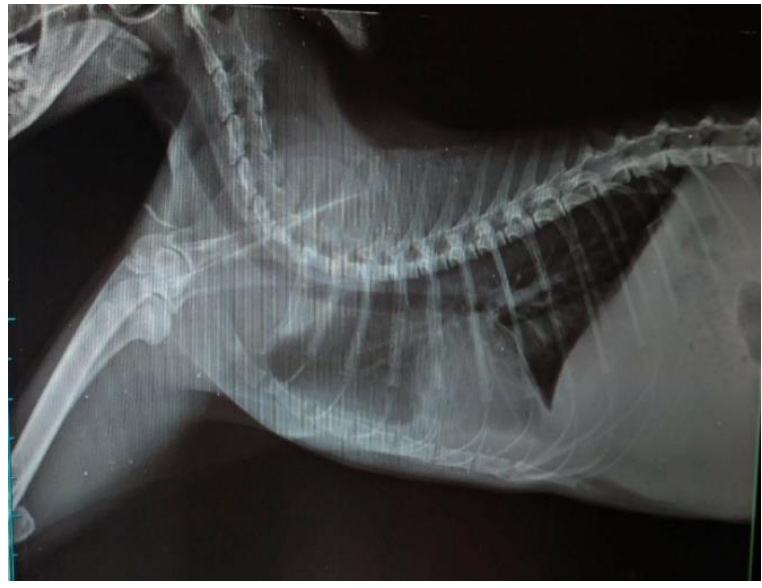

Figura 6. Raio-X de tórax na posição laterolateral com discreta efusão.

Diante dos achados no raio-X iniciou-se antibioticoterapia com doxiciclina na dose de $10 \mathrm{mg} / \mathrm{kg} \mathrm{SID,}$ $\mathrm{VO}$, a dose de prednisolona passou para $2 \mathrm{mg} / \mathrm{kg}$ SID, mantendo as medicações anteriores. Alguns dias após animal começou a demonstrar sinais neurológicos, como incoordenação motora.

No retorno (19/02/2020), tutor relatou que animal comia pouquíssimo e cada vez mais piorava a incoordenação, relatou ainda que viu o felino lambendo a parede. No exame físico observou desidratação moderada, mucosas oral e ocular estavam intensamente hipocoradas, diminuição do líquido abdominal, escore corporal baixo, na palpação abdominal rins estavam aumentados, incoordenação motora, tempo de preenchimento e turgor cutâneo maior que dois segundos e notou- se pequeno nódulo na pata torácica esquerda, segundo proprietário havia surgido recentemente. Foi solicitado hemograma e bioquímico (creatinina, ureia, AST, ALT e GGT). Na terapêutica a única mudança foi na dose de prednisolona que aumentou para $4 \mathrm{mg} / \mathrm{kg}$ SID.

No segundo hemograma, o eritrograma mostrou anemia, rouleaux eritrocitário, discreta anisocitose e hipocromia e howell jolly (+--); no leucograma os linfócitos estavam bem abaixo dos valores de referências (linfopenia), outros achados inclui trombocitopenia com presença de plaquetas gigantes e proteínas totais plasmáticas acima dos valores de referências. Nas dosagens bioquímicas ureia e creatinina estavam bem elevadas, indicando dano renal, além do ALT e AST acima dos valores de referências, demonstrando distúrbios das funções hepatobiliar. 
Em contato com o tutor, o mesmo relatou que o animal teve uma piora significativa do quadro clínico, como nos sintomas neurológicos, tendo grande dificuldade para ficar em pé, além da dispneia mais severa, vindo a óbito no dia 23 de fevereiro. $\mathrm{O}$ animal foi encaminhado para necrópsia no mesmo dia.

A necrópsia foi realizada no dia 23 de fevereiro de 2020, na avaliação externa o animal apresentava baixo estado de nutrição, mucosas pálidas e abaulamento flácido do abdômen, notou-se nódulo na pata torácica esquerda medindo em torno de $1 \mathrm{~cm}$. Ao exame interno, pode-se observar, icterícia no tecido subcutâneo, acúmulo de cerca de $40 \mathrm{~mL}$ de líquido livre na cavidade abdominal (Figura 7), que era viscoso e amarelo dourado na cavidade abdominal, fibrina dispersa na cavidade abdominal.

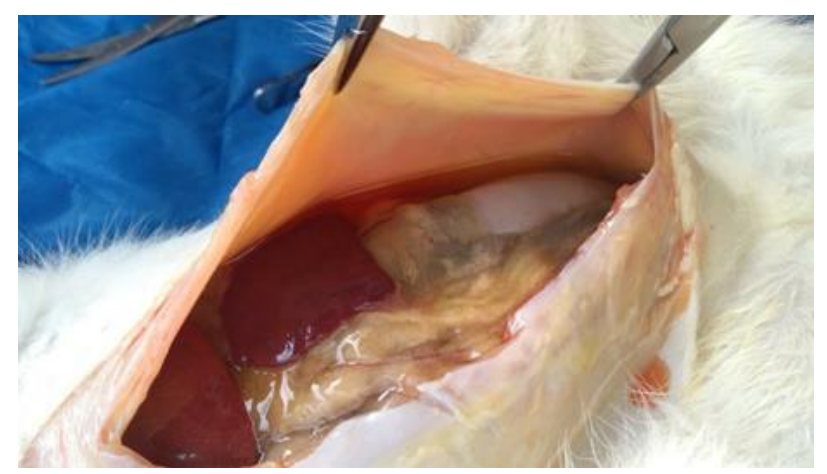

Figura 7. Presença de líquido livre na cavidade abdominal.

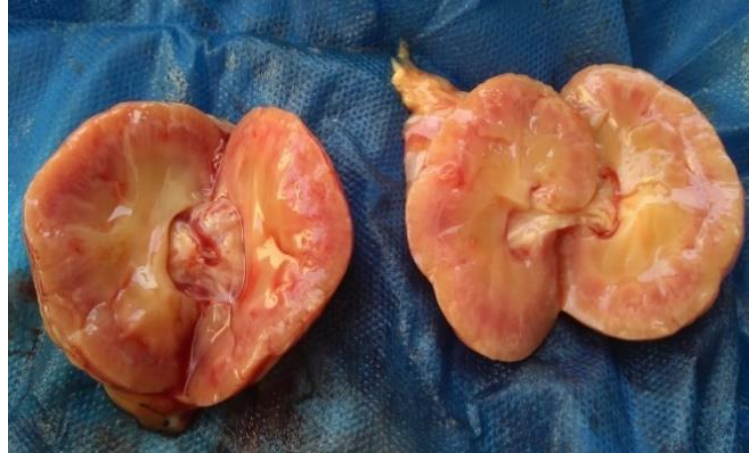

Figura 8. Rins com perda da distinção corticomedular.

Mesentério e omento espessados e opacos, formando uma massa compacta no abdome aderido entre si e outros órgão abdominais, ambos os rins estavam aumentados, com perda da distinção corticomedular (Figura 8), baço aumentado. A superfície do pulmão encontrava-se úmida, brilhante (devido infiltrado inflamatório), pálido possivelmente devido a anemia e efusão pleural. Cavidade pericárdica apresentando líquido viscoso. Fígado apresentou-se vermelho alaranjado e aumentado. Por meio da anamnese, sinais clínicos, exames de sangue, bioquímicos, analise do líquido da efusão, exames de imagem, RT-PCR e da necrópsia, o diagnóstico foi de peritonite infecciosa felina.

\section{Discussão}

O gato descrito tinha 1 anos de idade, estando entre a faixa etária mais acometida pela PIF. Segundo Worthing et al. (2012) a maioria dos felinos diagnosticados são animais jovens, na faixa etária de três meses a três anos de idade. Para Jericó et al. (2015), o estresse é dos fatores predisponente, situações como cirurgias, idas para gatis ou hotéis, mudanças de meio ambiente podem favorecer $o$ desenvolvimento da doença. Neste caso, animal passou por uma cirurgia, o que pode tê-lo predisposto a PIF.

$\mathrm{Na}$ anamnese, tutor relatou que animal vivia nas ruas até ser resgatado, sendo possível que esse animal já tivesse entrado em contado com o vírus e fosse portador do coronavírus felino, visto que ficava em contato constante com outros gatos. De acordo com Uliana et al. (2013) e Casagrande \& Machado (2016) as maiores incidências do vírus ocorrem em gatis e outros ambientes que abriguem maior número de animais, pela facilidade de transmissão orofecal.

Os sinais clínicos apresentados eram condizentes com a doença, que segundo Pedersen (2014) cursa com sinais de febre intermitente, acumulo de líquido abdominal, apatia, perda de peso, dispneia e sinais neurológicos. Os sinais da doença são inespecíficos, sendo parecidos a outras enfermidades infecciosas. À medida que a doença avança, os sinais clínicos tendem a piorar, ocorrendo o surgimento de outros sintomas (Moraillon et al., 2013). No caso citado os sinais clínicos evoluíram para incoordenação motora, caracterizando um quadro neurológico que pode ser observado na PIF.

Conforme Little (2016) as alterações cutâneas são manifestações incomuns da PIF não efusiva, caracterizadas por lesões nodulares decorrentes de flebite, ligeiramente elevadas e bem circunscritas sobre o pescoço e os membros torácicos e pélvicos. O felino descrito apresentou pequeno nódulo na pata torácica esquerda com tais características. 
Segundo Tsai et al. (2011) pode ocorrer a combinação das formas efusivas e não efusivas, com transição entre as duas em qualquer gato com PIF, uma forma rara, descrita em apenas 11,8\% dos gatos com PIF. No caso exposto o animal apresentou as duas formas, a princípio com a forma úmida com grande acúmulo de líquido da cavidade abdominal e dias depois a forma seca caracterizada pelo início dos sinais neurológicos.

A realização de exames de imagem, como radiografia e ultrassonografia auxilia na detecção de efusão abdominal e pleural, além de evidenciar alterações nos órgãos afetados (Fraga et al., 2011; Lewis et al., 2010). Nos dois exames de ultrassonografia realizados, apresentaram alterações nos rins, bexiga, fígado, estômago, baço, intestino, linfadenopatia e líquido livre no abdômen e no tórax. O raio-X realizado revelou alteração no pulmão, o mesmo apresentava padrão brônquio intersticial, caracterizando uma pneumonia, concordando com Oliveira et al. (2003) e Uliana et al. (2013) que descreveram o mesmo achado em animais com PIF.

O VPIF infecta células renais de gato, ocorrendo modulação na expressão de citocinas que pode ocasionar uma glomerulopatia devido à deposição de imunocomplexos. A continuidade das lesões ocorre com a infiltração de monócitos nos glomérulos (Safi et al., 2017), justificando as alterações encontradas nos rins do animal descrito.

Alterações hematológicas podem estar presentes e incluem leucocitose, neutrofilia, linfopenia, trombocitopenia e anemia (Little, 2016). No caso apresentado foi descrita tais alterações que são característicos da PIF, uma doença inflamatória. A linfopenia é a resposta leucocitária mais comum na maioria das doenças sistêmicas. pode estar ocorrendo pela liberação de hormônio adrenocorticotrófico pela glândula pituitária (hipófise), que resulta na liberação de cortisol pela glândula adrenal. Isso ocorre em resposta à maioria das condições como a doença inflamatória, responsável pela dor ou estresse, ocasionando o sequestro de linfócitos para os linfonodos e linfocitolise no tecido linfoide (Thrall, 2015). Sykes (2013) afirma que a contagem leucocitária pode estar aumentada ou diminuída, ocorrendo com maior frequência leucocitose.

Um dos achados mais comum é a trombocitopenia, sendo essa alteração encontrada em ambos os hemogramas realizados. A trombocitopenia pode ocorrer devido à presença de coagulação intravascular disseminada (CID), onde ocorre o aumento da reatividade das plaquetas, necrose hepática difusa e presença de lesões endoteliais ou destruição plaquetária imunomediada, esta destruição ocorre por ligação de anticorpos à superfície da plaqueta com consequente destruição pelos macrófagos, podendo a sua causa primária ser uma infecção viral como a PIF ( $\underline{\text { Sykes, 2013) }}$.

As dosagens bioquímicas podem indicar envolvimento de órgãos abdominais como nos rins (aumento de creatinina e ureia sanguínea), fígado e vesícula biliar (aumento de ALT e AST), além de acometer outros órgãos, tais alterações foram vistas no felino. $\mathrm{O}$ que corrobora com os achados encontrados em felinos com PIF descrito por Birchard \& Sherding (2008). A concentração de proteínas totais em sangue de animais com PIF é normalmente alta, sendo as globulinas maiores que a albumina. A relação albumina/globulina $(\mathrm{A} / \mathrm{G})$ sérica menor ou igual a 0,4 indica fortemente a ocorrência de PIF (Addie, 2015), no caso do paciente, igual a 0,3.

$\mathrm{Na}$ análise da efusão, os resultados encontrados foram compatíveis com a literatura: líquido de cor amarelo palha a dourado, turvo, podendo ou não ser viscoso, elevada densidade (1.017 a 1.047) e elevado conteúdo proteico (Pedersen, 2014). De acordo com Fischer et al. (2013), o teste de Rivalta contribui para a suspeita de PIF, o animal apresentou teste de Rivalta negativo na primeira coleta de líquido abdominal, mas com resultado positivo na segunda amostra colhida dias depois.

Para Pedersen (2014), valores de relação albumina: globulina menores que 0,8 , existe probabilidade alta do animal apresentar a PIF (valor preditivo positivo de 92\%). Este animal apresentou relação albumina/ globulina de 0,5 aumentando assim a suspeita de PIF. Na citologia os neutrófilos e linfócitos caracterizaram uma inflamação piogranulomatosa, provavelmente devido a uma infecção viral.

O diagnóstico por RT-PCR em efusões buscando diretamente o agente tem um bom valor preditivo para o diagnóstico (Felten et al., 2017); porém, não se diferencia o vírus mutado do não mutado através da técnica, segundo (Little, 2016). Dessa forma o resultado do RT- PCR deve ser avaliado em conjunto com outros dados e não como diagnóstico definitivo. Assim como ocorreu no caso. 
Os achados na necrópsia estão de acordo com o relatado em gatos que apresentaram PIF. Foi observado presença de líquido livre na cavidade abdominal e tórax, caracterizando a forma efusiva de PIF (Little, 2016). Foram encontradas alterações no baço (esplenomegalia), no fígado, estômago, linfonodos e nos rins, além de fibrina recobrindo o omento, o mesentério e a serosa intestinal, assim como relatado por Jubb et al. (2007), confirmando as alterações hepática e renal evidenciadas em outros exames, assim como a PIF.

O diagnóstico definitivo de PIF é realizado por histopatológico e imuno-histoquímica, contudo um diagnóstico presuntivo pode ser baseado na anamnese em conjunto com alterações clínicas, exames laboratoriais e achados de necrópsia, presentes em um animal com suspeita de PIF (Jericó et al., 2015). Após a morte do animal relatado não foi possível realizar o histopatológico e nem imuno-histoquímica, mas com as alterações clínico-patológicas, bem como exames laboratoriais, exames de imagem, achados na necrópsia, RT-PCR e anamnese auxiliaram no diagnóstico de PIF.

Não há tratamento eficaz para a PIF, e grande parte da terapia é baseada no cuidado de suporte que podem melhorar a qualidade de vida e possivelmente, a sobrevida do felino (Sykes, 2013). Nelson \& Couto (2015) recomendam a administração de prednisolona nos animais infectados com PIF, no felino descrito mesmo com a administração de prednisolona, não foi possível reduzir as manifestações clínicas da doença que evolui para a forma seca da PIF com sinais neurológicos. Todavia, no primeiro exame de US indicou liquido livre no tórax, sendo iniciado a terapêutica com prednisolona, dias após foi realizado raio-X do tórax, sendo evidenciada pouquíssima efusão, fato que pode ser atribuído pelo uso do corticoide.

A antibioticoterapia empregada foi escolhida em decorrência da suspeita de pneumonia secundária a doença, segundo Sykes (2013) animais com PIF podem desenvolver infecções bacterianas secundárias, sendo indicado tratamento com antibióticos. A suplementação vitamínica nos casos de PIF é fornecida para os pacientes que apresentam baixo escore corporal ou que se encontram anorexos, esta suplementação é frequentemente incluída nas medidas terapêuticas de suporte (Fernandes et al., 2015; Oliveira et al., 2003; Uliana et al., 2013), assim como ocorreu nesse caso.

Os animais com sinais clínicos moderados podem sobreviver durante semanas e até meses com alguma qualidade de vida proporcionada pelo tratamento (Addie, 2015). No caso relatado o animal sobreviveu mais de 30 dias, desde o início dos primeiros sinais clínicos, vindo a óbito após iniciar sinais neurológicos.

\section{Considerações finais}

A Peritonite Infecciosa Felina é uma doença grave e fatal e de diagnóstico difícil in vivo, podendo ocorrer a apresentação das duas formas no mesmo animal e transição entre as duas. No caso relatado o diagnóstico só foi possível pela associação de uma boa anamnese, exame físico, exames de imagem, RT-PCR, necrópsia, exames laboratoriais e análise do líquido da efusão. O tratamento instituído não foi capaz de parar a progressão da doença, mas melhorou a qualidade de vida do felino.

\section{Dedicatória}

À nossa querida amiga Edilene Pereira de Sousa (in memoriam), que sempre esteve presente em nossas vidas de maneira física, mas agora está em nossos corações para sempre. A sua amizade fortaleceu nosso vínculo, nos tornando mais íntimos e amados, assim como sua garra para concretizar a sua tão sonhada faculdade de veterinária. A ela dedicamos este trabalho, onde é possível observar os resultados dos seus esforços e o seu amor por nós e pela medicina veterinária. Com muita gratidão.

\section{Referências}

Addie, D. D. (2015). Infecções pelo coronavírus felino. In Doenças infecciosas em cães e gatos. Editora Record. Birchard, S. J., \& Sherding, R. G. (2008). Manual Saunders: clínica de pequenos animais. In Ed. Roca (Vol. 3).

Casagrande, T., \& Machado, D. D. (2016). Peritonite Infecciosa Felina: Relato de dois casos clínicos. Revista Ciência \& Cidadania, 2(1), 103-109.

Felten, S., Matiasek, K., Gruendl, S., Sangl, L., Wess, G., \& Hartmann, K. (2017). Investigation into the 
utility of an immunocytochemical assay in body cavity effusions for diagnosis of feline infectious peritonitis. Journal of Feline Medicine and Surgery, 19(4), 410-418. https://doi.org/10.1177/1098612X16630357.

Fernandes, M. H. V., Cargnelutti, J. F., Masuda, E. K., \& Hübner, S. O. (2015). Peritonite infecciosa felina-Relato de caso. Science And Animal Health, 3(2), 181-191. https://doi.org/10.15210/sah.v3i2.5490.

Fischer, Y., Weber, K., Sauter-Louis, C., \& Hartmann, K. (2013). The Rivalta's test as a diagnostic variable in feline effusions-evaluation of optimum reaction and storage conditions. Tierärztliche Praxis Ausgabe K: Kleintiere/Heimtiere, 41(5), 297-303.

Fraga, E., Barreiro, J. D., Goicoa, A., Espino, L., Fraga, G., \& Barreiro, A. (2011). Abdominal ultrasonographic findings in dogs naturally infected with babesiosis. Veterinary Radiology \& Ultrasound, 52(3), 323-329.

Jericó, M. M., Kogika, M. M., \& Andrade Neto, J. P. (2015). Tratado de medicina interna de cães e gatos. Guanabara Koogan.

Jubb, K. V. F., P.C., K., \& M.G., M. (2007). Pathology of domestic animals (Vol. 2). Academic press.

Lewis, K., O’Brien, M., \& Robert, T. (2010). Abdominal ultrasonographic findings associated with feline infectious peritonitis: A Retrospective review of 16 cases. Journal of the American Animal Hospital Association, 46(3), 152-160.

Little, S. E. (2016). O gato: medicina interna. Editora Roca.

Megid, J., Ribeiro, M. G., \& Paes, A. C. (2016). Doenças infecciosas em animais de produção e de companhia. Roca.

Moraillon, R., Legeay, Y., Boussarie, D., \& Sénécat, O. (2013). Manual Elsevier de Veterinária: Diagnóstico e tratamento de Cães, gatos e animais exóticos (7th ed.). Elsevier.

Nelson, R. W., \& Couto, C. G. (2015). Medicina interna de pequenos animais (Issue 1). Elsevier Editora.

Oliveira, F. N., Raffi, M. B., Souza, T. M., \& Barros, C. S. L. (2003). Peritonite infecciosa felina: 13 casos. Ciência Rural, 33(5), 905-911. https://doi.org/10.1590/s0103-84782003000500018.

Pedersen, N. C. (2014). An update on feline infectious peritonitis: Virology and immunopathogenesis. The Veterinay Journal, 2, 123-132.

Safi, N., Haghani, A., Ng, S. W., Selvarajah, G. T., Mustaffa-Kamal, F., \& Omar, A. R. (2017). Expression profiles of immune mediators in feline Coronavirus-infected cells and clinical samples of feline Coronavirus-positive cats. BMC Veterinary Research, 13(1), 1-13. https://doi.org/10.1186/s12917-017-1019-2.

Sharif, S., Arshad, S. S., Hair-Bejo, M., Omar, A. R., Zeenathul, N. A., \& Alazawy, A. (2010). Diagnostic methods for feline coronavirus: A review. Veterinary Medicine International, 1-7. https://doi.org/10.4061/2010/809480.

Sykes, J. E. (2013). Canine and feline infectious diseases-E-Book. Elsevier Health Sciences. https://doi.org/10.1016/C2009-0-41370-9.

Thrall, M. A. (2015). Hematologia e Bioquímica Clínica Veterinária. In 2. ed. Editora Roca.

Tsai, H.-Y., Chueh, L.-L., Lin, C.-N., \& Su, B.-L. (2011). Clinicopathological findings and disease staging of feline infectious peritonitis: 51 cases from 2003 to 2009 in Taiwan. Journal of Feline Medicine and Surgery, 13(2), 74-80. https://doi.org/10.1016/j.jfms.2010.09.014.

Uliana, L. M. A., Brito, H. F. V., Montaño, P. Y., Laskosky, L. M., Knopf, T. de A., \& Locatelli-Dittrich, R. (2013). Peritonite infecciosa felina. MEDVEP - Revista Científica de Medicina Veterinária, 10(35), 46-53.

Worthing, K. A., Wigney, D. I., Dhand, N. K., Fawcett, A., McDonagh, P., Malik, R., \& Norris, J. M. (2012). Risk factors for feline infectious peritonitis in Australian cats. Journal of Feline Medicine and Surgery, 14(6), 405-412. https://doi.org/10.1177/1098612X12441875.

Histórico do artigo:

Recebido: 8 de março de 2021

Aprovado: 15 de abril de 2021
Licenciamento: Este artigo é publicado na modalidade Acesso Aberto sob a licença Creative Commons Atribuição 4.0 (CC-BY 4.0), a qual permite uso irrestrito, distribuição, reprodução em qualquer meio, desde que o autor e a fonte sejam devidamente creditados. 